\title{
The Impact of Financial Access on Gender Unemployment: Panel Data Evidence from in 51 developed and developing countries
}

\author{
Khai Ying Eng, Chee-Hong Law* and Yiing Jia Loke \\ ${ }^{1}$ Economics Section, School of Social Sciences \\ Universiti Sains Malaysia \\ *Corresponding author: cheehong@usm.my
}

\begin{abstract}
Unemployment is a frequently debated issue, and the issue has become more pressing since studies have indicated that females and males are encountering degrees of unemployment. This study investigates the influence of financial access on unemployment between females and males. Data from 51 developed and developing countries from 2004 to 2016 is analysed by deploying the dynamic panel system generalized method of moments estimators. This paper contributes to the literature by utilising the number of bank branches and automated teller machines to proxy financial access indicators. The availability of the papers that examine these indicators is limited. Besides, this study is novel because no attempt has been made to compare the effect of financial access on female and male unemployment using a panel dataset. The results showed that financial access indicators positively associate with female and male unemployment, probably due to the detrimental effect of financing on job creation. In addition, the positive relationship between employment and financial access is more significant for male unemployment than female unemployment, which might relate to the argument that males are more exposed to formal financial services. Furthermore, bank branches have a more noticeable impact and stronger influence than automated teller machines in affecting female and male unemployment rates. This paper suggests that governments need to improve the financial system to create the positive impacts of financial access on employment and reduce negative shocks to the economy via formal financial institutions. Lastly, alternative financial channels, such as microfinance, could be promoted as an alternative to formal financial institutions.
\end{abstract}

Keywords: Financial Inclusion, Unemployment Rate, Panel Data, System Generalized Method of Moments

\section{Introduction}

The International Labour Organization (2019) defines the unemployed as 'all those of working age who were not in employment, carried out activities to seek employment during a specified recent period'. Further, Keynes (1936) proposes that involuntary unemployment occurs when an increase in the price level reduces real wages, lowering the labour supply. Unemployment is usually attributed to lack of information, low labour demand and the slow adjustment of wages due to the fixed contractual setting (Brunner \& Meltzer, 1978). Moreover, labour market rigidities such as generous unemployment insurance schemes, high unemployment protection, severe tax distortions, and non-competitive wage-setting mechanisms are also considered important factors contributing to high unemployment levels (Nickell, Nunziata, Ochel and Quintini, 2001; International Monetary Fund, 2003).

Unemployment is a critical economic phenomenon and could result in negative consequences such as deteriorating people's well-being. For example, unemployment could 
create social unrest and psychological stress (Pervaiz, 2012). Nonetheless, research that examines the linkages between access to finance and the unemployment rate is relatively scant compared with research that studied the implications of financial development on the other macroeconomic variables. Furthermore, the previous findings are inconclusive, calling for further exploration of the linkage. Compared to previous attempts, this study contributes to the literature by comparing the effects of access to finance on female and male unemployment using same country sample set. Moreover, to my best understanding, this papers also offers empirical evidence from panel estimation which has not been conducted before.

Some researchers have investigated the connection between financial access and unemployment. For instance, Aliero and Ibrahim (2012) argued that enhancing access to financial services in rural areas reduces poverty and the unemployment rate in developing countries. Besides, Dabla-Norris, Kochhar, Suphaphiphat, Ricka, and Tsounta (2015) investigated how lowering monitoring costs and relaxing collateral requirements increase firms' access to credit, as this credit access, in turn, enhances economic growth, increases labour demand and improves the production process. Besides, Aterido, Hallward-Driemeier and Carmen (2007) explore the impacts of access to finance, corruption and regulations across firms on employment growth using data from 70,000 enterprises in 107 countries from 2000 to 2006. They proposed that poor access to finance decreased firms' size distribution and slowed down all firms' employment expansion, especially small-medium firms. The International Finance Corporation (2013) states that enhancing access to finance benefits firms by enlarging their operations, which results in a positive outcome on the quality and jobs creation.

This paper examines the impact of financial access on gender unemployment using a balanced panel dataset covering 51 countries with annual data from 2004 to 2016 . The dataset is selected based on data availability. This paper contributes to the current literature by assessing whether access to finance will affect the unemployment between males and females, which has not been explored extensively. Compared with previous studies, which only looked at the overall unemployment rate, the present paper takes a step further by looking at the female and male unemployment rates. Furthermore, the output will provide additional insights into the financial access-unemployment nexus, especially in formulating the appropriate policy by testing the country-level aggregate data. The following section contains the literature review. Section 3 describes the data and presents the hypothetical relationships between the dependent and independent variables. The next section covers the methodology, and section 5 discusses the panel data results. The final section concludes and suggests policy recommendations.

\section{Literature Review}

The literature reviewed that most relevant studies investigated the impact of financial inclusion or access to finance in creating jobs and employment at the firm level. However, few papers have studied the relative impact on unemployment among females and males, not to mention studies examining country-level data. For example, Niemi (1974) and Rayman (1987) found that women have a higher unemployment rate than men because women are more likely to involve in household activities such as preparing food and caring for children. Besides, social and cultural factors also do not encourage women to work. It results in higher unemployment for women. Blau and Ferber (1991) found a similar result. They showed that the weaker female labour force attachment (elasticity of labour force participation) raised their unemployment rate. 
On the other hand, some research had opposite opinions. Ayyagari, Juarros, Peria, Soledad and Singh (2016) argued that firms might expand by increasing their investments. Thus, output increases from greater access to finance without increasing the demand for labour. This situation is a form of "jobless growth". This argument is supported by Bein and Ciftcioglu (2017), which suggested that for firms that have a production technology in which capital and labour are substitutable, an increase in capital investment following accessibility to financing facilities may reduce firms' labour demand, lowering job creation. The finding implies that financial access does not necessarily lead to job creation if the firms are not labour intensive.

Selected evidence has put forward by examining the financial inclusion effect across gender. For example, using survey data from 2007 to 2011, Mattingly, Smith and Bean (2011) examined changes in unemployment patterns by sex, age, education, race and ethnicity, marital status, and parental status. The result indicated that throughout the great recession, the unemployment rate is highest among men. This argument was supported by Verick (2009), which focused on the impact of the financial crises on OECD countries. The paper described the long-term economic downturn in different countries such as Finland, Japan, Norway, Sweden; the results reflected that compared with others, young men suffered a higher unemployment rate in the previous and current 2008 economic downturn.

\section{Hypothetical Relationships}

The implication of financial access to unemployment could be expressed twofold. Firstly, the increasing penetration of ATMs has improved financial inclusion and work as an effective tool to provide access to financial services to rural and unbanked areas in India (Gupta, 2008). A well-developed ATM and bank branches can accelerate long-run economic growth by decreasing transaction costs and increasing credit access (Petkovski \& Kjosevski, 2014). More coverage of ATM and bank branches will encourage firms to invest in more capital and hire more labour. According to Acemoglu (2001), low access to finance can affect unemployment; he concluded that low access to finance restricts new firms' development and negatively affects job creation. Second, financial access could hurt the unemployment rate. In particular, the firms may utilise bank loans more on capital goods instead of labour-intensive technology in their production process. Garmaise (2008) supported this by arguing that removing finance restrictions may allow firms to optimally substitute capital for labour and prefer to invest in capital-intensive technologies. Consequently, it increases unemployment.

According to Okun's law (1970), real output influences unemployment negatively (Cuaresma, 2003). Simultaneously, discrimination could occur between male and female in obtaining benefit from economic growth because men will normally have better job opportunities and socio-economic status than women, who are usually the minority within an occupation or work environment. Previous studies suggested that the gender-based bias in work is even greater for the upper class than in the middle-class group (Bowles, Babcock \& McGinn, 2005). The human capital theory of Becker (1962) suggested that formal education plays a significant role in improving production capacity. Subsequently, the earning of workers and employability will increase. In other words, higher education attainment enables people to have more occupation choices. However, the opposite impact could be possible. Lavrinovicha (2015) examined the impact of education on Latavia's unemployment rate from 2002 to 2013. The author concluded that there is a positive relationship between education level and the unemployment rate. This positive relationship is possible if women with higher education are 
displaced from the job market due to a mismatch between job requirements and education, which commonly occurred in developing countries (Farooq, 2011).

Furthermore, the Phillips curve (1958) implies an inverse relationship between inflation and unemployment (Phillip, 1958; Cutler \& Katz, 1991). Samuelson and Nordhaus (2000) support the negative association by mentioning that a nation can lower its unemployment level if it is willing to accept a higher inflation rate. Finally, the Ricardian model proposed a comparative advantage model and predicted that trade openness and unemployment are negatively related. However, there are also previous studies that found opposing views. Autor, Dorn and Hanson (2013) mentioned that an increase in imports would increase the unemployment rate and reduce labour force participation. They justify the claim by suggesting a significant negative relationship between international trade (USA and China) and labour supply. Helpman and Itskhoki (2010) found that open trade will increase a country's unemployment rate if its relative labour market frictions in the differentiated sector are low. Fugazza, Carrère, Olarreaga and Robert-Nicoud (2014) concurred with this claim and found a positive relationship between trade and unemployment in countries having a comparative advantage in sectors with high labour market frictions. Besides, Davis and Harrigan (2011) argued that trade liberalisation might destroy plenty of job opportunities, especially in the economic sectors with high marginal production costs or provide high wages but low productivity.

\section{Methodology}

This paper estimated the following equation to achieve the research objective. The same equation is applied to examine the impact of financial access on female and male unemployment

$$
U N E M_{t}=\alpha_{1}+\alpha_{2} U N E M_{t-1}+\alpha_{3} L F A_{t}+\alpha_{4} G D P G_{t}+\alpha_{5} E D U_{t}+\alpha_{6} I N_{t}+\alpha_{7} L T R A_{t}+\eta+
$$
$\varepsilon_{i t}$

where $U N E M$ is the unemployment rate., $L F A$ is the natural logarithm of the financial access indicators applied in this paper, GDPG is the growth rate of real gross domestic product, $E D U$ is the education attainment indicator measured by secondary school gross enrolment rate, IN denotes inflation rate, and LTRA is the natural logarithm of trade openness. Finally, the $\eta$ and $\varepsilon$ indicate the unobserved country-specific effect independently and the identically distributed error team.

The dependent variables of this paper are female and male unemployment rates. Several previous studies have applied the same indicator to measure unemployment status. Gatti, Rault and Vaubourg (2009) used the unemployment rate as the dependent variable to determine how labour interact with financial factors to determine unemployment. Bein and Ciftcioglu (2017) adopted the unemployment rate to explore the relationship between financial sector development and unemployment in selected countries in the European Union. The data is available from the World Bank database.

This study applied four financial access indicators which are the number of automated teller machines (ATMs) per thousand kilometres square, the number of ATM per hundred thousand adults, the number of bank branches per thousand kilometres square and the number of bank branches per hundred thousand adults to measure the degree of financial access. These data are available in the Financial Access Survey (FAS) database. The FAS database collects annual data on indicators that track financial access, providing extensive coverage of 152 time- 
series data for 47 financial indicators. It can be grouped by geographic outreach and the use of financial services. Previous studies such as Degryse and Ongena (2005), Sarma (2008), Sophastienphong and Kulathunga (2008) have employed ATMs and bank branches to indicate the degree of access to finance in their study. Moreover, several control variables are included in the unemployment equations to improve the estimated coefficients' causal interpretation and avoid omitted variables bias. These variables are inflation rate (percentage), growth rate of the real gross domestic product (percentage), secondary school enrolment rate (percentage) and trade openness (percentage of gross domestic product, GDP). These data are obtained from the World Bank database

The financial institution access index from the IMF Financial Development database is deployed to test the results' sensitivity to that alternative financial access indicator. The financial institution access index combines both the number of ATM and bank branches per hundred thousand adults. In addition, another equation is applied as another robustness check. In this robustness estimation, the impact of financial access on female and male employment is examined; equation (2) illustrates the estimated model

$$
E M_{t}=\alpha_{1}+\alpha_{2} E M_{t-1}+\alpha_{3} L F A_{t}+\alpha_{4} G D P G_{t}+\alpha_{5} E D U_{t}+\alpha_{6} I N_{t}+\alpha_{7} L T R A_{t}+\eta+\varepsilon_{i t}
$$

where $E M$ is female and male employment. It is assumed that the coefficient of financial access in equation (2) will hold the sign that opposite to equation (1). For example, if the result of equation (1) indicates that financial access will increase the female and male unemployment rate, equation (2) should indicate a negative relationship between financial access and the female and male employment rate. The estimation is conducted on the baseline model, i.e. representing the financial access with the number of bank branches per thousand-kilometre square. The maximum two lagged of the dependent variable will be treated as the instrument variables.

Estimation wise, the system generalized method of moments (S-GMM) estimator developed by Blundell and Bond (1998) is applied here. This method accounts for the fixed effects and consists of a differenced equation and a level equation. The estimation of level and differenced equations makes the estimator include additional moment conditions that rely on the initial observation's stationary conditions. The stationarity conditions are due to the dependent variable's persistence properties. This additional moment is absent in the difference GMM; it means the difference GMM only contains the moment conditions for a level equation. Instruments variables are tested in the S-GMM to overcome the endogeneity bias and serial correlation in a dynamic panel model. The difference and level equation's instruments are the endogenous variables in level and the endogenous variables in the first differenced, respectively. Although the S-GMM estimators improve estimation efficiency compared with the difference GMM estimation, the greater instrument variables involved in the S-GMM estimation could lead to instrument proliferation. This paper avoids instrument proliferation by limiting the number of lags used as instruments. The rule of thumb is that the number of lags should be lower than the number of cross-sectional units. The Stata code xtdpdsys is used for the estimation.

Moreover, the Sargan test and the autoregressive (AR) autocorrelation test are applied to test the instruments' validity and confirm the absence of the second-order autocorrelation of the residuals, respectively. The null hypothesis of the Sargan test is that the instruments are valid, while the AR autocorrelation tests the null hypothesis of no second-order autocorrelation. The result's robustness is confirmed by testing the model with different control variables and 
examined using the 2-year average data. The results of the averaged data in general concurs with the impact of financial access on unemployment but are not reported here to conserve space; the outpute are available upon request. Finally, Cook's Distance Outlier test (Cook, 1977) is used to detect outliers that may influence the estimation result and the regression's slope; these outliers are excluded from estimations.

\section{Results and Discussions}

Tables 1 to Table 4 presented the estimation outputs that examine the implication of financial access measured by ATM and bank penetration indicators on female and male unemployment rates. As mentioned, the ATM indicators are the ATMs per thousand kilometres squared and ATMs per hundred thousand adults. Otherwise, the bank branches indicators are the bank branches per thousand kilometre squared and bank branches per hundred thousand adults. The Sargan test did not reject the over-identification restrictions at a 5\% significance level in all estimations, validating the identifications imposed in the GMM estimations. Furthermore, the second-order AR autocorrelation test (AR2) failed to reject the null hypothesis of no secondorder autocorrelation, but the first order AR autocorrelation test (AR1) did. Hence, these results further support the validity of the estimated outputs.

The estimation results presented in Table 1 indicated that the number of bank branches per thousand-kilometre square has a positive and statistically significant impact on the female and male unemployment rate. The positive linkage between financial access and the unemployment rate is also found in other financial indicators (see Table 2 to Table 4); all of them are statistically significant. Moreover, male unemployment has greater reactions to financial access compared with female unemployment. A similar finding is shown in Table 2 and Table 3, which studied bank branches per thousand hundred adult and ATM per thousand kilometres square. However, this relatively stronger impact on male unemployment is not supported when the equation is tested with ATM pre hundred thousand adults (see Table 4). For the GDP growth, the results from Table 1 to Table 4 show a negative and statistically significant impact on the unemployment rate from the number of ATM and bank branches in term of thousand-kilometer square and hundred thousand adults.

Additionally, the result indicated that the secondary school enrollment level significantly negatively influences the female unemployment rate. Nonetheless, the effect turns positive for male unemployment. This peculiar result is not statistically significant when ATM and bank branches per 100,000 adults were used as financial access indicator, indicating that there is no consistent evidence to conclude the impact of education on male unemployment is statistically significant. The estimations also show a positive (negative) relationship between inflation and female (male) unemployment rates. In other words, only the impact of the inflation rate on the male unemployment rate is consistent with the theory discussed above. Finally, trade openness showed a positive relationship with the unemployment rate in both genders except for the estimation involving ATM coverage per 100,000 adults. 
Borneo Journal of Social Sciences \& Humanities DOI: https://doi.org/10.35370/bjssh.2021.3.1-08 e-ISSN: 2682-8235

(C) 2018, UCTS Publisher.

Submitted: 1 April 2021

Accepted: 10 June 2021

Published: 30 June 2021

Table 1 Female and Male Unemployment Rate Equation (Financial Access Indicator: Number of Bank Branches per $1000 \mathrm{~km}^{2}$ )

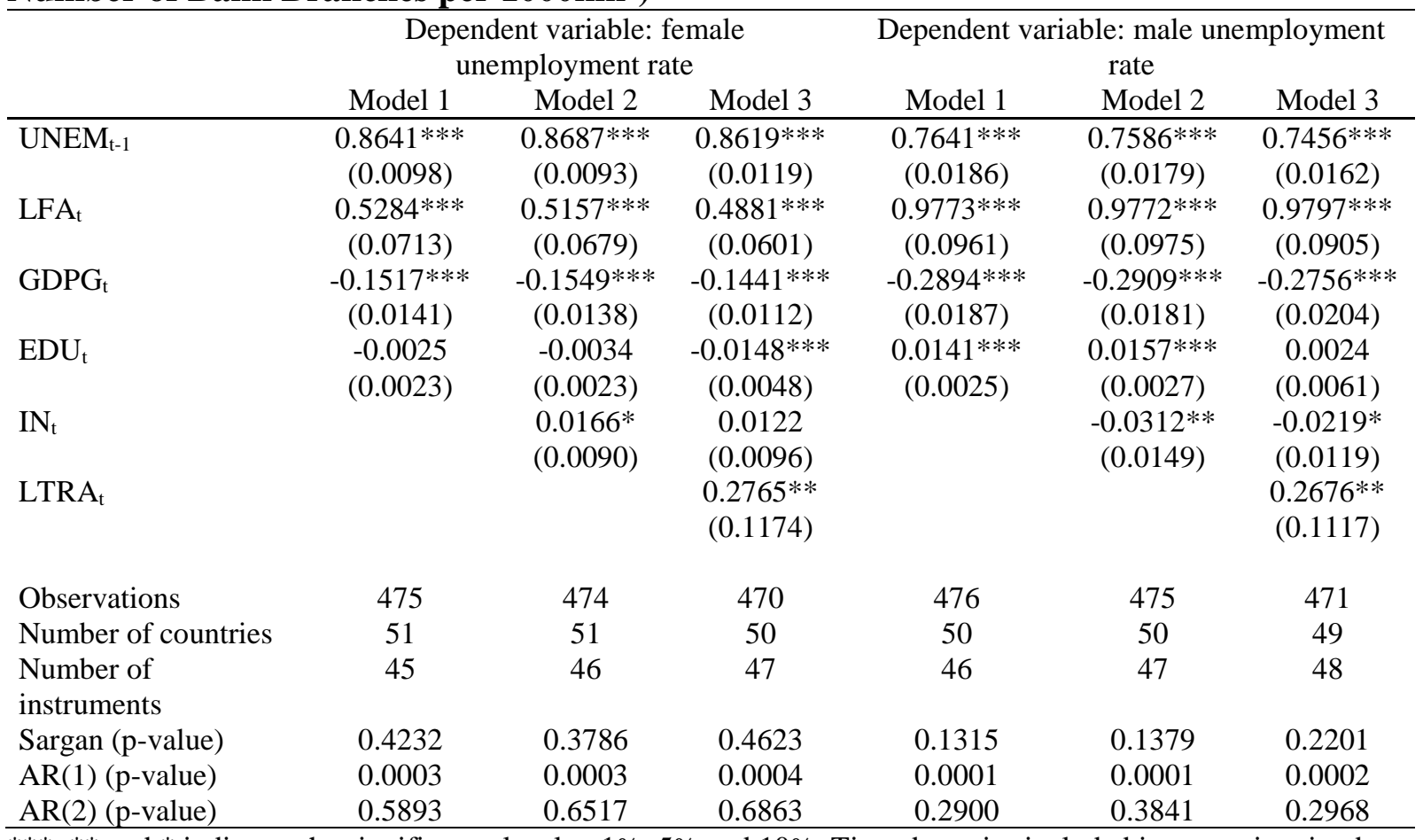

$* * *, * *$ and $*$ indicates the significance level at $1 \%, 5 \%$ and $10 \%$. Time dummies included in our estimation but not presented to conserve space.

Source: Author

Table 2 Female and Male Unemployment Rate Equation (Financial Access Indicator: Number of Bank Branches per 100,000 Adults)

\begin{tabular}{|c|c|c|c|c|c|c|}
\hline & \multicolumn{3}{|c|}{$\begin{array}{l}\text { Dependent variable: female } \\
\text { unemployment rate }\end{array}$} & \multicolumn{3}{|c|}{$\begin{array}{l}\text { Dependent variable: male unemployment } \\
\text { rate }\end{array}$} \\
\hline & Model 1 & Model 2 & Model 3 & Model 1 & Model 2 & Model 3 \\
\hline $\mathrm{UNEM}_{\mathrm{t}-1}$ & $\begin{array}{c}0.8748 * * * \\
(0.0112)\end{array}$ & $\begin{array}{c}0.8780 * * * \\
(0.0105)\end{array}$ & $\begin{array}{c}0.8956 * * * \\
(0.0135)\end{array}$ & $\begin{array}{c}0.7614 * * * \\
(0.0225)\end{array}$ & $\begin{array}{c}0.7597 * * * \\
(0.0207)\end{array}$ & $\begin{array}{c}0.7542 * * * \\
(0.0187)\end{array}$ \\
\hline $\mathrm{LFA}_{t}$ & $\begin{array}{c}1.1428 * * * \\
(0.1118)\end{array}$ & $\begin{array}{c}1.1699 * * * \\
(0.1221)\end{array}$ & $\begin{array}{c}1.1452 * * * \\
(0.1207)\end{array}$ & $\begin{array}{c}2.2987 * * * \\
(0.3355)\end{array}$ & $\begin{array}{c}2.2645 * * * \\
(0.3385)\end{array}$ & $\begin{array}{c}2.4593 * * * \\
(0.3184)\end{array}$ \\
\hline $\mathrm{GDPG}_{\mathrm{t}}$ & $\begin{array}{c}-0.1244 * * * \\
(0.0115)\end{array}$ & $\begin{array}{c}-0.1261^{* * * *} \\
(0.0106)\end{array}$ & $\begin{array}{c}-0.1324 * * * \\
(0.0099)\end{array}$ & $\begin{array}{c}-0.2613 * * * \\
(0.0209)\end{array}$ & $\begin{array}{c}-0.2613 * * * \\
(0.0213)\end{array}$ & $\begin{array}{c}-0.2533 * * * \\
(0.0203)\end{array}$ \\
\hline $\mathrm{EDU}_{\mathrm{t}}$ & $\begin{array}{c}-0.0152 * * * \\
(0.0040)\end{array}$ & $\begin{array}{c}-0.0172 * * * \\
(0.0045)\end{array}$ & $\begin{array}{l}-0.0136 * * \\
(0.0054)\end{array}$ & $\begin{array}{c}0.0010 \\
(0.0050)\end{array}$ & $\begin{array}{c}0.0004 \\
(0.0049)\end{array}$ & $\begin{array}{c}0.0007 \\
(0.0048)\end{array}$ \\
\hline $\mathrm{IN}_{\mathrm{t}}$ & & $\begin{array}{c}0.0229 * * \\
(0.0111)\end{array}$ & $\begin{array}{l}0.0350 * * * \\
(0.0125)\end{array}$ & & $\begin{array}{l}-0.0303^{*} \\
(0.0167)\end{array}$ & $\begin{array}{c}-0.0337 * * \\
(0.0167)\end{array}$ \\
\hline $\mathrm{LTRA}_{t}$ & & & $\begin{array}{l}-0.1136 \\
(0.0959)\end{array}$ & & & $\begin{array}{c}0.3932 \\
(0.3057)\end{array}$ \\
\hline Observations & 477 & 476 & 472 & 479 & 478 & 474 \\
\hline Number of countries & 51 & 51 & 50 & 50 & 50 & 49 \\
\hline $\begin{array}{l}\text { Number of } \\
\text { instruments }\end{array}$ & 45 & 46 & 47 & 46 & 47 & 48 \\
\hline Sargan (p-value) & 0.6316 & 0.6105 & 0.5880 & 0.1948 & 0.1970 & 0.1796 \\
\hline AR(1) (p-value) & 0.0003 & 0.0003 & 0.0003 & 0.0002 & 0.0001 & 0.0002 \\
\hline AR(2) (p-value) & 0.6720 & 0.7425 & 0.7344 & 0.2331 & 0.2830 & 0.2753 \\
\hline
\end{tabular}


Borneo Journal of Social Sciences \& Humanities

DOI: https://doi.org/10.35370/bjssh.2021.3.1-08

e-ISSN: 2682-8235

(C) 2018, UCTS Publisher.

Submitted: 1 April 2021

not presented to conserve space.

Source: Author

Table 3 Female and Male Unemployment Rate Equation (Financial Access Indicator: Number of ATM per $1000 \mathrm{~km}^{2}$ )

\begin{tabular}{|c|c|c|c|c|c|c|}
\hline & \multicolumn{3}{|c|}{$\begin{array}{l}\text { Dependent variable: female } \\
\text { unemployment rate }\end{array}$} & \multicolumn{3}{|c|}{$\begin{array}{l}\text { Dependent variable: male unemployment } \\
\text { rate }\end{array}$} \\
\hline & Model 1 & Model 2 & Model 3 & Model 1 & Model 2 & Model 3 \\
\hline $\mathrm{UNEM}_{\mathrm{t}-1}$ & $\begin{array}{l}0.9266 * * * \\
(0.0115)\end{array}$ & $\begin{array}{c}0.9282 * * * \\
(0.0108)\end{array}$ & $\begin{array}{l}0.9354 * * * \\
(0.0124)\end{array}$ & $\begin{array}{c}0.7861 * * * \\
(0.0204)\end{array}$ & $\begin{array}{l}0.7784 * * * \\
(0.0204)\end{array}$ & $\begin{array}{c}0.7691 * * * \\
(0.0193)\end{array}$ \\
\hline $\mathrm{LFA}_{\mathrm{t}}$ & $\begin{array}{l}0.6078 * * * \\
(0.0710)\end{array}$ & $\begin{array}{l}0.6001 * * * \\
(0.0676)\end{array}$ & $\begin{array}{l}0.5570 * * * \\
(0.0756)\end{array}$ & $\begin{array}{c}0.8524 * * * \\
(0.0823)\end{array}$ & $\begin{array}{c}0.8814 * * * \\
(0.0839)\end{array}$ & $\begin{array}{c}0.8205 * * * \\
(0.0956)\end{array}$ \\
\hline $\mathrm{GDPG}_{\mathrm{t}}$ & $\begin{array}{c}-0.1307 * * * \\
(0.0135)\end{array}$ & $\begin{array}{c}-0.1360 * * * \\
(0.0136)\end{array}$ & $\begin{array}{l}-0.1349 * * * \\
(0.0125)\end{array}$ & $\begin{array}{c}-0.2845^{* * *} \\
(0.0209)\end{array}$ & $\begin{array}{l}-0.2926 * * * \\
(0.0197)\end{array}$ & $\begin{array}{c}-0.2783^{* * *} \\
(0.0204)\end{array}$ \\
\hline $\mathrm{EDU}_{\mathrm{t}}$ & $\begin{array}{l}-0.0052 * \\
(0.0031)\end{array}$ & $\begin{array}{c}-0.0059 * * \\
(0.0029)\end{array}$ & $\begin{array}{l}-0.0103 * \\
(0.0057)\end{array}$ & $\begin{array}{c}0.0067 * * * \\
(0.0021)\end{array}$ & $\begin{array}{l}0.0086 * * * \\
(0.0023)\end{array}$ & $\begin{array}{l}-0.0012 \\
(0.0046)\end{array}$ \\
\hline $\mathrm{IN}_{\mathrm{t}}$ & & $\begin{array}{l}0.0266 * * * \\
(0.0088)\end{array}$ & $\begin{array}{l}0.0307 * * * \\
(0.0090)\end{array}$ & & $\begin{array}{l}-0.0415 * * * \\
(0.0152)\end{array}$ & $\begin{array}{c}-0.0315 * * \\
(0.0128)\end{array}$ \\
\hline $\mathrm{LTRA}_{t}$ & & & $\begin{array}{c}0.1231 \\
(0.0991)\end{array}$ & & & $\begin{array}{c}0.2253 * * \\
(0.1027)\end{array}$ \\
\hline Observations & 486 & 485 & 481 & 486 & 485 & 481 \\
\hline Number of countries & 51 & 51 & 50 & 50 & 50 & 49 \\
\hline $\begin{array}{l}\text { Number of } \\
\text { instruments }\end{array}$ & 45 & 46 & 47 & 46 & 47 & 48 \\
\hline Sargan (p-value) & 0.5097 & 0.5424 & 0.5385 & 0.1175 & 0.0964 & 0.2074 \\
\hline AR(1) (p-value) & 0.0003 & 0.0003 & 0.0003 & 0.0001 & 0.0001 & 0.0001 \\
\hline $\mathrm{AR}(2)(\mathrm{p}$-value) & 0.6994 & 0.7680 & 0.7999 & 0.2960 & 0.4578 & 0.3563 \\
\hline
\end{tabular}

***, $* *$ and $*$ indicates the significance level at $1 \%, 5 \%$ and $10 \%$. Time dummies included in our estimation but not presented to conserve space.

Source: Author

Table 4 Female and Male Unemployment Rate Equation (Financial Access Indicator: Number of ATM per 100,000 Adults)

\begin{tabular}{|c|c|c|c|c|c|c|}
\hline & \multicolumn{3}{|c|}{$\begin{array}{c}\text { Dependent variable: female } \\
\text { unemployment rate }\end{array}$} & \multicolumn{3}{|c|}{$\begin{array}{c}\text { Dependent variable: male unemployment } \\
\text { rate }\end{array}$} \\
\hline & Model 1 & Model 2 & Model 3 & Model 1 & Model 2 & Model 3 \\
\hline $\mathrm{UNEM}_{\mathrm{t}-1}$ & $\begin{array}{c}0.9036 * * * \\
(0.0114)\end{array}$ & $\begin{array}{c}0.9034 * * * \\
(0.0108)\end{array}$ & $\begin{array}{c}0.9311 * * * \\
(0.0122)\end{array}$ & $\begin{array}{c}0.8160 * * * \\
(0.0163)\end{array}$ & $\begin{array}{c}0.8123 * * * \\
(0.0155)\end{array}$ & $\begin{array}{c}0.8235 * * * \\
(0.0146)\end{array}$ \\
\hline $\mathrm{LFA}_{t}$ & $\begin{array}{l}0.8526 * * * \\
(0.0661)\end{array}$ & $\begin{array}{l}0.8252 * * * \\
(0.0627)\end{array}$ & $\begin{array}{l}0.8131 * * * \\
(0.0571)\end{array}$ & $\begin{array}{c}0.6526 * * * \\
(0.1082)\end{array}$ & $\begin{array}{c}0.6771 * * * \\
(0.1130)\end{array}$ & $\begin{array}{c}0.8009 * * * \\
(0.1192)\end{array}$ \\
\hline $\mathrm{GDPG}_{\mathrm{t}}$ & $\begin{array}{c}-0.1494 * * * \\
(0.0113)\end{array}$ & $\begin{array}{c}-0.1545^{* * *} \\
(0.0114)\end{array}$ & $\begin{array}{c}-0.1438 * * * \\
(0.0105)\end{array}$ & $\begin{array}{c}-0.3008 * * * \\
(0.0153)\end{array}$ & $\begin{array}{c}-0.2944 * * * \\
(0.0165)\end{array}$ & $\begin{array}{c}-0.2870 * * * \\
(0.0190)\end{array}$ \\
\hline $\mathrm{EDU}_{\mathrm{t}}$ & $\begin{array}{c}-0.0165 * * * \\
(0.0035)\end{array}$ & $\begin{array}{c}-0.0160 * * * \\
(0.0034)\end{array}$ & $\begin{array}{c}-0.0166 * * * \\
(0.0060)\end{array}$ & $\begin{array}{c}0.0000 \\
(0.0032)\end{array}$ & $\begin{array}{c}0.0009 \\
(0.0035)\end{array}$ & $\begin{array}{c}0.0018 \\
(0.0035)\end{array}$ \\
\hline $\mathrm{IN}_{\mathrm{t}}$ & & $\begin{array}{c}0.0246 * * * \\
(0.0093)\end{array}$ & $\begin{array}{c}0.0311 * * * \\
(0.0100)\end{array}$ & & $\begin{array}{c}-0.0422 * * * \\
(0.0158)\end{array}$ & $\begin{array}{c}-0.0314 * * \\
(0.0142)\end{array}$ \\
\hline LTRA $_{t}$ & & & $\begin{array}{c}-0.0572 \\
(0.1217)\end{array}$ & & & $\begin{array}{c}-0.1565 \\
(0.0967)\end{array}$ \\
\hline Observations & 481 & 480 & 476 & 487 & 486 & 482 \\
\hline Number of countries & 51 & 51 & 50 & 50 & 50 & 49 \\
\hline $\begin{array}{l}\text { Number of } \\
\text { instruments }\end{array}$ & 45 & 46 & 47 & 44 & 45 & 46 \\
\hline Sargan (p-value) & 0.4540 & 0.4541 & 0.5275 & 0.2119 & 0.2510 & 0.2094 \\
\hline
\end{tabular}


Borneo Journal of Social Sciences \& Humanities

DOI: https://doi.org/10.35370/bjssh.2021.3.1-08

e-ISSN: 2682-8235

(C) 2018, UCTS Publisher.

Submitted: 1 April 2021

Accepted: 10 June 2021

Published: 30 June 2021

\begin{tabular}{lllllll}
$\mathrm{AR}(1)$ (p-value) & 0.0003 & 0.0002 & 0.0003 & 0.0001 & 0.0001 & 0.0001 \\
$\mathrm{AR}(2)$ (p-value) & 0.5000 & 0.5635 & 0.6021 & 0.3221 & 0.4421 & 0.3924 \\
\hline
\end{tabular}

$* * *, * *$ and $*$ indicates the significance level at $1 \%, 5 \%$ and $10 \%$. Time dummies included in our estimation but not presented to conserve space.

Source: Author

This positive effect of the number of bank branches per thousand-kilometre square on the female and male unemployment rate is in line with Garmaise (2008) argument that reducing finance restrictions encourages firms to invest in more capital-intensive technologies, replacing capital for labour in the process. Eventually, it worsens the employment rate of both female and male. In other words, this paper rejects the positive implication of financial access to job creation. Moreover, the relatively stronger negative impact on male unemployment is similar to the finding in the paper of Verick (2009) and Mattingly et al. (2011). In this case, the stronger impact could be because traditionally, males have more exposure to the formal financial services offered by banks. Hence, if financial access weakens employment creation, as presented in the introduction, the impact on male unemployment will be larger. After reviewing Table 1 to Table 4, we found that bank branches' coefficient is higher than ATM, which means that bank branches have a greater impact on female and male unemployment rates as branches often provide more service, especially the lending facilities.

For the GDP growth, the result is consistent with the hypothesis where real output influences unemployment negatively. The finding is in sequence with Noor, Zaleha \& Mohamed Nor, Norashidah, Ghani and Judhiana (2007) which presented a negative relationship between output and unemployment in Malaysia. Furthermore, this paper hypothesises that secondary school enrollment should negatively affect education level and the unemployment rate. Additionally, the inverse relationship between education level and female unemployment rate contradicts Farooq (2011) conclusion that educated women experience more unemployment. Instead, a better education level will improve female productivity and enable them to participate more in the labour market, substantiating the typical assumption that education improves women's job opportunities.

Moroever, the finding show that only the impact of the inflation rate on the male unemployment rate is consistent with the theory discussed above. Finally, the positive coefficient sign of trade openness is consistent with the arguments that trade openness has a detrimental effect on job markets, as argued by Autor et al. (2013), Davis and Harrigan (2011) and Fugazza et al. (2014). Nonetheless, this negative sign is not robustly supported in all examined financial access indicators.

Two robustness analyses are deployed to confirm the positive coefficient of financial access. First, Table 5 replacing the financial access indicator with the financial institution access index, and Table 6 changes the dependent variable into female and male employment rate and control variables remain unchanged. The Sargan test did not reject the overidentification restrictions at a 5\% significance level in both estimations, validating the identifications imposed in the GMM estimations. Furthermore, the second-order AR autocorrelation test (AR2) failed to reject the null hypothesis of no second-order autocorrelation, but the first order AR autocorrelation test (AR1) did. Hence, these results further support the validity of the estimated outputs. Table 5 produces the conclusion consistent with that of the main estimation result. On the other hand, Table 6 shows that financial access has a negative relationship with the female and male employment rate and has a greater impact on male unemployment. In other words, this robustness analysis offers more evidence to substantiate the rejection of the positive implication from financial access to job creation. 
Borneo Journal of Social Sciences \& Humanities DOI: https://doi.org/10.35370/bjssh.2021.3.1-08 e-ISSN: 2682-8235

(C) 2018, UCTS Publisher.

Submitted: 1 April 2021

Accepted: 10 June 2021

Published: 30 June 2021

Table 5 Female and Male Unemployment Rate Equation (Financial Access Indicator: IMF Financial Institution Access Index)

\begin{tabular}{|c|c|c|c|c|c|c|}
\hline & \multicolumn{3}{|c|}{$\begin{array}{c}\text { Dependent variable: female } \\
\text { unemployment rate }\end{array}$} & \multicolumn{3}{|c|}{$\begin{array}{l}\text { Dependent variable: male unemployment } \\
\text { rate }\end{array}$} \\
\hline & Model 1 & Model 2 & Model 3 & Model 1 & Model 2 & Model 3 \\
\hline $\mathrm{UNEM}_{\mathrm{t}-1}$ & $\begin{array}{c}0.8970 * * * \\
(0.0158)\end{array}$ & $\begin{array}{c}0.8975 * * * \\
(0.0146)\end{array}$ & $\begin{array}{c}0.9080 * * * \\
(0.0135)\end{array}$ & $\begin{array}{c}0.7345 * * * \\
(0.0227)\end{array}$ & $\begin{array}{c}0.7334 * * * \\
(0.0230)\end{array}$ & $\begin{array}{c}0.7521 * * * \\
(0.0226)\end{array}$ \\
\hline LFA $_{t}$ & $\begin{array}{l}4.3057 * * * \\
(0.5155)\end{array}$ & $\begin{array}{c}4.1750 * * * \\
(0.5096)\end{array}$ & $\begin{array}{l}3.9344 * * * \\
(0.4305)\end{array}$ & $\begin{array}{l}6.7818 * * * \\
(1.0701)\end{array}$ & $\begin{array}{l}6.6780 * * * \\
(1.0526)\end{array}$ & $\begin{array}{c}6.6501 * * * \\
(1.0333)\end{array}$ \\
\hline $\mathrm{GDPG}_{\mathrm{t}}$ & $\begin{array}{c}-0.1368 * * * \\
(0.0124)\end{array}$ & $\begin{array}{c}-0.1452 * * * \\
(0.0130)\end{array}$ & $\begin{array}{c}-0.1493 * * * \\
(0.0119)\end{array}$ & $\begin{array}{c}-0.2212 * * * \\
(0.0124)\end{array}$ & $\begin{array}{l}-0.2200 * * * \\
(0.0133)\end{array}$ & $\begin{array}{c}-0.2155^{* * * *} \\
(0.0125)\end{array}$ \\
\hline $\mathrm{EDU}_{\mathrm{t}}$ & $\begin{array}{c}-0.0145 * * * \\
(0.0030)\end{array}$ & $\begin{array}{c}-0.0145 * * * \\
(0.0030)\end{array}$ & $\begin{array}{c}-0.0164 * * * \\
(0.0063)\end{array}$ & $\begin{array}{r}-0.0088^{*} \\
(0.0049)\end{array}$ & $\begin{array}{l}-0.0075 \\
(0.0050)\end{array}$ & $\begin{array}{c}0.0003 \\
(0.0047)\end{array}$ \\
\hline $\mathrm{IN}_{\mathrm{t}}$ & & $\begin{array}{l}0.0410 * * * \\
(0.0122)\end{array}$ & $\begin{array}{l}0.0453 * * * \\
(0.0113)\end{array}$ & & $\begin{array}{l}-0.0184 \\
(0.0128)\end{array}$ & $\begin{array}{l}-0.0144 \\
(0.0123)\end{array}$ \\
\hline $\mathrm{LTRA}_{\mathrm{t}}$ & & & $\begin{array}{c}0.0502 \\
(0.1151)\end{array}$ & & & $\begin{array}{l}-0.1941 \\
(0.1315)\end{array}$ \\
\hline Observations & 474 & 473 & 469 & 484 & 483 & 479 \\
\hline Number of countries & 50 & 50 & 49 & 50 & 50 & 49 \\
\hline $\begin{array}{l}\text { Number of } \\
\text { instruments }\end{array}$ & 42 & 43 & 44 & 44 & 45 & 46 \\
\hline Sargan (p-value) & 0.1479 & 0.3000 & 0.4296 & 0.0983 & 0.1085 & 0.1148 \\
\hline AR(1) (p-value) & 0.0005 & 0.0005 & 0.0005 & 0.0004 & 0.0004 & 0.0004 \\
\hline $\mathrm{AR}(2)$ (p-value) & 0.6506 & 0.7721 & 0.7647 & 0.2412 & 0.2646 & 0.2618 \\
\hline
\end{tabular}

***, ** and * indicates the significance level at $1 \%, 5 \%$ and $10 \%$. Time dummies included in our estimation but not presented to conserve space.

Source: Author

Table 6 Female and Male Employment Rate With the Number of Bank Branches per $1000 \mathrm{~km}^{2}$ (Financial Access Indicator: Number of Bank Branches per ThousandKilometre Square)

\begin{tabular}{|c|c|c|c|c|c|c|}
\hline & \multicolumn{3}{|c|}{$\begin{array}{l}\text { Dependent variable: female employment } \\
\text { rate }\end{array}$} & \multicolumn{3}{|c|}{ Dependent variable: male employment rate } \\
\hline & Model 1 & Model 2 & Model 3 & Model 1 & Model 2 & Model 3 \\
\hline \multirow[t]{2}{*}{$\mathrm{UNEM}_{\mathrm{t}-1}$} & $0.7930 * * *$ & $0.7926 * * *$ & $0.7958 * * *$ & $0.7808 * * *$ & $0.7728 * * *$ & $0.7828 * * *$ \\
\hline & $(0.0254)$ & $(0.0268)$ & $(0.0289)$ & $(0.0143)$ & $(0.0151)$ & $(0.0189)$ \\
\hline \multirow{2}{*}{$\mathrm{LFA}_{\mathrm{t}}$} & $-0.4843 * * *$ & $-0.4901 * * *$ & $-0.4663 * * *$ & $-1.0760 * * *$ & $-1.0605 * * *$ & $-0.9369 * * *$ \\
\hline & $(0.1087)$ & $(0.1279)$ & $(0.1554)$ & $(0.1518)$ & $(0.1518)$ & $(0.1982)$ \\
\hline \multirow[t]{2}{*}{$\mathrm{GDPG}_{\mathrm{t}}$} & $0.0653 * * *$ & $0.0633 * * *$ & $0.0630 * * *$ & $0.1598 * * *$ & $0.1594 * * *$ & $0.1584 * * *$ \\
\hline & $(0.0070)$ & $(0.0070)$ & $(0.0076)$ & $(0.0144)$ & $(0.0157)$ & $(0.0173)$ \\
\hline \multirow[t]{2}{*}{$\mathrm{EDU}_{\mathrm{t}}$} & 0.0028 & 0.0038 & 0.0002 & -0.0042 & -0.0034 & -0.0003 \\
\hline & $(0.0058)$ & $(0.0059)$ & $(0.0055)$ & $(0.0063)$ & $(0.0062)$ & $(0.0056)$ \\
\hline \multirow[t]{2}{*}{$\mathrm{IN}_{\mathrm{t}}$} & & -0.0074 & -0.0085 & & $0.0348 * * *$ & $0.0297 * * *$ \\
\hline & & $(0.0071)$ & $(0.0076)$ & & $(0.0113)$ & $(0.0107)$ \\
\hline \multirow[t]{2}{*}{$\mathrm{LTRA}_{t}$} & & & $-0.4820 * *$ & & & 0.0793 \\
\hline & & & $(0.2251)$ & & & $(0.4438)$ \\
\hline Observations & 471 & 470 & 466 & 494 & 493 & 489 \\
\hline Number of countries & 48 & 48 & 48 & 51 & 51 & 51 \\
\hline $\begin{array}{l}\text { Number of } \\
\text { instruments }\end{array}$ & 46 & 47 & 48 & 46 & 47 & 48 \\
\hline Sargan (p-value) & 0.2235 & 0.2233 & 0.2219 & 0.3764 & 0.3762 & 0.5132 \\
\hline AR(1) (p-value) & 0.0035 & 0.0037 & 0.0041 & 0.0205 & 0.0189 & 0.0195 \\
\hline AR(2) (p-value) & 0.0869 & 0.0824 & 0.0831 & 0.4516 & 0.5524 & 0.5270 \\
\hline
\end{tabular}


Borneo Journal of Social Sciences \& Humanities

DOI: https://doi.org/10.35370/bjssh.2021.3.1-08

e-ISSN: 2682-8235

(C) 2018, UCTS Publisher.

Submitted: 1 April 2021

Accepted: 10 June 2021

Published: 30 June 2021

$* * *, * *$ and $*$ indicates the significance level at $1 \%, 5 \%$ and $10 \%$. Time dummies included in our estimation but not presented to conserve space.

Source: Author

\section{Conclusion}

This paper examines the impact of financial access on the gender unemployment rate in 51 countries from 2004 to 2016. It examines the impact of financial access on the gender unemployment rate is critical because there is a lack of studies that compare female and male unemployment in the same paper, even though financial access is believed to bring about advantages to the economy. This paper's findings showed that financial access could harm unemployment, which is observed in higher unemployment for both genders. Moreover, the results propose that men suffer more from greater unemployment when financial access improves, implying that males, in general, are more exposed to the influence of formal finance. The GDP growth rate holds a negative relationship with unemployment rates for both genders, while education only reduces female unemployment. There is evidence to suggest that trade openness could increase unemployment as well.

In addition, the impact brought by the accessibility of bank branches is worse off than those of the ATMs. The more significant role from bank branches is probably because bank branches provide more functions, especially the loan transactions that profoundly impact job creation. Finally, the conclusions are mainly supported by the robustness estimations. The positive association between financial access and unemployment suggests that the government should review the current role of bank branches and ATMs in driving financial access to ensure the positive spill-over from financial access. It includes government regulations to mitigate the negative impacts of economic turmoil on the real economy that transmit to the real economy via banking institutions. Furthermore, the financing channels that support job creation and entrepreneurship, such as microfinance, could be promoted instead of depending on the formal financial institutions. Finally, one thing that should be considered in this study is the small sample size. The sample size is limited due to the short duration and the limited coverage of the data. Additional research is needed to evaluate the industrial impact of financial access on the gender unemployment, to assess whether financial access narrows the gender unemployment gap in a uniform pattern across primary, secondary and tertiary economic sectors.

\section{References}

Acemoglu, D. (2001). Credit Market Imperfections and Persistent Unemployment. European Economic Review, 45(4-6), 665-679.

Aliero, H. M.,1. \& Ibrahim, S.S. (2012). The relationship between energy consumption and economic growth in Nigeria: A causality analysis. International Journal of Marketing and Technology, 2, $1-13$.

Aterido, R., Hallward-Driemeier, M., \& Carmen, P. (2007). Investment Climate and Employment Growth: The Impact of Access to Finance, Corruption and Regulations across Firms (Institute for the Study of Labour (IZA) Discussion Paper No.3138). $\begin{array}{lllll}\text { Retrieved on } 25 \text { July } 2019 . & \text { Retrieved from }\end{array}$ 
https://www.iza.org/publications/dp/3138/investment-climate-and-employmentgrowth-the-impact-of-access-to-finance-corruption-and-regulations-across-firms

Autor, D., Dorn, D., \& Hanson, G. H. (2013). The China Syndrome: Local Labor Market Effects of Import Competition in the United States. American Economic Review, 103(6), 2121-2168.

Ayyagari, M., Juarros, P., Peria, M., Soledad, M. S. M., \& Singh, S. (2016). Access to finance and job growth: firm-level evidence across developing countries (World Bank Policy Research Working Paper No. 6704). Retrieved on 27 July 2019. Retrieved from http://documents1.worldbank.org/curated/en/804781467990954208/pdf/WPS7604.pdf

Becker, G. (1962). Investment in human capital: A theoretical analysis. Journal of Political Economy, 70(5), 9-49.

Bein M. A. \& Ciftcioglu, S. (2017). The relationship between the relative GDP share of agriculture and the unemployment rate in selected Central and Eastern European countries. Agricultural. Economics - Czech, 63(7), 308-317.

Blau, F. \& Ferber, M. (1991). Career Plans and Expectations of Young Women and Men: The Earnings Gap and Labor Force Participation. Journal of Human Resources, 26(4), 581607.

Blundell, R. \& Bond, S. (1998). Initial conditions and moment restrictions in dynamic panel data models. Journal of Econometrics, 87(1), 115-143.

Bowles, H. R., Babcock, L., \& McGinn, K. L. (2005). Constraints and triggers: Situational mechanics of gender in negotiation. Journal of Personality and Social Psychology, 89(6), 951-965.

Brunner, K. \& Meltzer, A. H. (1978). The theory of employment and unemployment (Konstanz seminar paper 5-1978). Retrieved on 25 July 2019. Retrieved from file:///C:/Users/k/Downloads/TheTheoryofEmploymentandUnemployment.pdf

Cook, R. D. (1977). Detection of Influential Observation in Linear Regression. Technometrics, 19(1), 15-18.

Cuaresma, J. C. (2003). Okun's Law Revisited. Oxford Bulletin of Economics and Statistics, 65(4), 439-451.

Cutler, D. M. \& Katz, L. F. (1991). Macroeconomic Performance and the Disadvantaged. Brookings Papers on Economic Activity, 22(2), 1-74.

Dabla-Norris, E., Kochhar, K., Suphaphiphat, N., Ricka, F. \& Tsounta, F. (2015). Causes and Consequences of Income Inequality: A Global Perspective Era (IMF Staff Discussion Notes 15/13). Retrieved on 17 July 2019. Retrieved from https://www.imf.org/external/pubs/ft/sdn/2015/sdn1513.pdf

Davis, D. R. \& Harrigan, J. (2011). Good jobs, bad jobs, and trade liberalization. Journal of International Economics, 84(1), 26-36.

Degryse, H. \& Ongena, S. (2005). Distance, lending relationships, and competition. The Journal of Finance, 60(1), 231-266.

Farooq, S. (2011). Mismatch Between Education and Occupation: A Case Study of Pakistani Graduates. Pakistan Development Review, 50(4), 531-552.

Fugazza, M., Carrère, C., Olarreaga, M., \& Robert-Nicoud, F. (2014). Trade in Unemployment (Policy Issues in International Trade and Commodities Research Study Series number 
Borneo Journal of Social Sciences \& Humanities DOI: https://doi.org/10.35370/bjssh.2021.3.1-08 e-ISSN: 2682-8235

(C) 2018, UCTS Publisher.

Submitted: 1 April 2021

64). Retrieved on 1 August 2019. Retrieved from https://unctad.org/system/files/official-document/itcdtab64_en.pdf

Garmaise, M. J. (2008). Production in Entrepreneurial Firms: The Effects of Financial Constraints on Labor and Capital. Review of Financial Studies, 21(2), 543-577.

Gatti, D., Rault, C., \& Vaubourg, A. A. G. (2009). Unemployment and Finance: How do Financial and Labour Market Factors Interact? Retrieved on 18 July 2019. Retrieved from https://www.cesifo.org/DocDL/cesifo1_wp2901.pdf

Gupta, D. K. (2008). Mother Tongue Friendly e-Delivery Banking Channels in India-Ultimate Solution for its Popular Usage. Retrieved on 30 July 2019. Retrieved from https://papers.ssrn.com/sol3/papers.cfm?abstract_id=2894129

Helpman, E. \& Itskhoki, O. (2010). Labour Market Rigidities, Trade and Unemployment. The Review of Economic Studies, 77(3), 1100-1137.

International Finance Corporation (2013). Assessing private sector contributions to job creation and poverty reduction. (IFC discussion paper 83508). Retrieved from http://documents1.worldbank.org/curated/en/157191468326714061/pdf/835080WP0I FC0J00Box382079B00PUBLIC0.pdf

International Labour Organization. (2019). Quick guide on interpreting the unemployment rate. Geneva: International Labour Organisation.

International Monetary Fund. (2003). Unemployment and labor market institutions: Why reforms pay off. In World Economic Outlook, April 2003 by International Monetary Fund (Ed), pp.129-150.

Keynes, J. M. (1936) The General Theory of Employment, Interest and Money. United Kingdom: Palgrave Macmillan.

Lavrinovicha, I. (2015). Influence of education on unemployment rate and incomes of residents. Social and Behavioral Sciences, 174, 3824-3831.

Mattingly, M.J., Smith, K., \& Bean, J. A. (2011). Unemployment in the Great Recession: single parents and men hit hard (Carsey institute Issue Paper). Retrieved on 16 July 2019. Retrieved from https://scholars.unh.edu/carsey/144/

Nickell, S. J., Nunziata, L., Ochel, W., \& Quintini, G. (2001) The Beveridge curve, unemployment and wages in the OECD from the 1960s to the 1990s (CEP Discussion Papers 0502). Retrieved on 14 July 2019. Retrieved from https://ideas.repec.org/p/cep/cepdps/dp0502.html

Niemi, B. (1974). The Female-Male Differential in Unemployment Rate. Industrial and Labor Relations Review, 27(3), 331-350.

Noor, Z. \& Mohamed Nor, N., \& Ghani, J. (2007). The Relationship between output and unemployment in Malaysia: Does Okun's Law exist? International Journal of economics and management, 1(3), 337-344

Petkovski, M. \& Kjosevski, J. (2014). Does banking sector development promote economic growth? An empirical analysis for selected countries in Central and South Eastern Europe. Economic Research-Ekonomska Istraživanja, 27(1), 55-66.

Phillips, A. W. (1958). The relation between unemployment and the rate of change of money wage rates in the United Kingdom, 1861-1957. Economics, 25(100), 283-299.

Rayman, P. M. (1987). Women and Unemployment. Social Research, 54(2), 355-376.

Samuelson, P. \& Nordhaus, W. (2009). Economics (19th ed.) NY: McGraw-Hill Education. 
Borneo Journal of Social Sciences \& Humanities

DOI: https://doi.org/10.35370/bjssh.2021.3.1-08

e-ISSN: 2682-8235

(C) 2018, UCTS Publisher.

Submitted: 1 April 2021

Accepted: 10 June 2021

Published: 30 June 2021

Sarma, M. (2008). Index of financial inclusion (CRIER Working Paper No. 215). Retrieved on 15 July 2019. Retrieved from http://www.icrier.org/pdf/Working_Paper_215.pdf

Sophastienphong, K. \& Kulathunga, A. (2008). Getting finance in South Asia 2009: indicators and analysis of the commercial banking sector. Washington, D.C.: World Bank.

Verick, S. (2009) Who is Hit Hardest During a Financial Crisis? The Vulnerability of Young Men and Women to Unemployment in an Economic Downturn (IZA Discussion Paper No. 4359). Retrieved on 17 July 2019. Retrieved from http://ftp.iza.org/dp4359.pdf 